\title{
Preliminary Phytochemical Screening (Qualitative Analysis) of Cacao Leaves (Theobroma Cacao L.)
}

\author{
H Parbuntari*, Y Prestica, R Gunawan, M N Nurman, F Adella \\ Chemistry Department, Faculty of Mathematics and Natural Science, Universitas \\ Negeri Padang \\ *Email: hesty5193@fmipa.unp.ac.id
}

\begin{abstract}
One of the important processes of cocoa plants growing is pruning. It aims to eliminate sick, broken, or the appearance of water buds disturbing the cacao production. The period of pruning is varios. The various periods of pruning lead to leave wide waste of leaves, stems, and twigs. Yet the waste would not been used to other activities, only a small portion of the waste used as natural fuel (stems and twigs) and cocoa leaves waste as animal feed. Phytochemicals naturally present in every part of plants range from leaves, stem bark, fruits to roots. Secondary metabolites are natural products from plants which include alkaloid, flavonoid, steroid, terpenoid, sapponin compounds, etc. This study performed some phytochemical characterisations. It have confirmed that cacoa leaves consist some of bioactives compounds which are potential for furhter activities in pharmaceutical disease.

Keywords : Preliminary, Phytochemical Screening, Cacao Leaves, Theobroma Cacao L. metabolites
\end{abstract}

\section{Introduction}

Cacao (Theobroma cacao L.) pruning has an important role in cocoa cultivation. It aims to maintain the shape of the cocoa plants that previously had good fruit quality, maintain the leaf spreading pattern, stimulate the formation of new fruits, flowers, and leaves[1-5]. Pruning which is one of the process of maintaining cocoa plants also aims to eliminate unwanted parts of plants such as branches that are sick, broken, or the appearance of water buds. Pruning is carried out in the frequency of one to two months with the quantity of pruning leaves or twigs that are not too much or adjusted to the needs. To accelerate flower and fruit growth, pruning can be done twice a year [6].

The pruning process is often carried out in different periods. The pruning process carried out at different time frequencies will produce cocoa leaves waste, stems and twigs. Heretofore, the waste from pruning has not been used to its full potential, only a small portion of the waste used as fuel (waste of stems and twigs) and cocoa leaves is used as animal feed [7]. According Supriyatno: 2014, stated that cocoa leaves can be used as tea leaves because cocoa leaves are believed to have quite high antioxidants[8].

Fruits and vegetables are source of many antioxidant compounds such as carotenoids, tocopherols, phenolics, and anthocyanins. Approximately $20 \%$ of identified plants have been introduced to pharmaceutical studies, focusing in the healthcare system such as cancer treatment and any harmful diseases. Plants synthesis a significant number of diverse of bioactive compounds. High portion of phytochemicals, which will be potensial for protecting to free radical damage, accumulate in vegetables and fruits. Free radicals that can damage cells in the body can be overcome by the presence of an antioxidant. Various types of diseases caused by free radicals such as liver and cancer[9]. 
1.1.Identification of the presence of an antioxidant is based on phytochemical approaches which leads to the drug discovery referred as natural product screening [10]. Every part of the plant may contain active components such as bark, leaves, flowers, roots, fruits and seeds [11]. Phytochemicals are wellknown as bioactive constituents of plants namely steroids, terpenoids, carotenoids, flavanoids, alkaloids, tannins and glycosides. Most studies said that these compounds have various activities range from antimicrobial to antibacterial. So, this study aims to confirm the presence of alkaloids, flavonoids, steroids, triterpenoids, and sapponins in cacoa leaves.

\section{Experimental Section}

2.1. An Alkaloid Identification (Method of Culvenor-Fitzgeraid)

1. 4 grams of cacao leaves were ground gently and added by chloroform as the solvent. The texture would be like a porridge.

2. The "porridge" was added by ammonia-chloroform solution $0,05 \mathrm{~N}$.

3. The mixture was filtered and collected the extract (liquid phase only) into a test tube

4. It was added by $5 \mathrm{~mL}$ of $\mathrm{H}_{2} \mathrm{SO}_{4} 2 \mathrm{~N}$ and strongly shaken.

5. By waiting about some minutes, the mixture would be two layers.

6. The layers should be separated. The upper layer was solution in $\mathrm{H}_{2} \mathrm{SO}_{4}$ and another one was solution solved in chloroform.

7. The chlorofom solution was stored for terpenoid test.

8. To a few $\mathrm{mL}$ of filtrate, a drop or two Mayer's reagent were added by the side of the test tube. A yellow precipitate indicated the test as positive.

9. To few $\mathrm{mL}$ of filtrate, 1 or $2 \mathrm{~mL}$ of Wagner's reagent were added by the side of the test tube. A prominent brown or yellow precipitate indicated the test as positive.

10. To a few mL of filtrate, a drop or two drops of Dragendorff's reagent were added by the side of the test tube. A prominent orange or yellow precipitate indicated the test as positive.

2.2. Flavonoid Identification: Shinoda test, sianidin test

1. 0,5 grams of cacao leaves were ground and extracted in $5 \mathrm{~mL}$ of methanol.

2. The extract was then heated approximately 5 minutes through the test tube.

3. The extract was added some drops of concentrated hydochloric acid and a few amount of magnesium powder.

4. The colour changing into red or pink indicated the sample containing flavonoid.

\subsection{Steroid/ Terpenoid Identification: Lieberman-Burchad Method}

1. A few drops of chloroform solution (The solution had been stored in Alkaloid identification) was dissolved in acetic anhydride.

2. To this one or two drops of concentrated sulphuric acid were added slowly along the side of the test tube.

3. An array of colour changes into orange or purple indicated the sample containing terpenoid while a blue colour change showed the positive result of steroid.

\subsection{Sapponins Identification}

1. To identify sapponin, the sample should be totally dried.

2. In case of wet sample, it should be boiled in aquadest for $2-3$ minutes.

3 . The suspension was shaken in a test tube for approximately 5 minutes.

41 IEKSAKTA: Berkala IImiah Bidang MIPA (Science Periods EKSAKTA of MIPA) 
4. A foam forming for about 5 minutes indicated the presence of sapponins.

\section{Result and Discussion}

Phytochemistry is a part of chemistry belonging to the chemical nature of the plant or plant products (chemistry of natural products). Plants which have many chemical constituents somehowe could be therapeutically active or inactive. A spectrum of natural compounds which exert physiological activities range from triterpenoids, alkaloids, glycosides, tannins, flavonoids, essential oils to other similar secondary metabolites are synthesised in the plants.

Phytochemical screening is an important step in the effort to uncover the potential of medicinal plant resources [12] as antibiotics, antioxidants, and anticancer [13]. This screening was carried out to provide an overview of the class of compounds contained in the chloroform extract of cocoa leaves and methanol extract for flavonoid testing. The extract that is formed is dark green. This extract is then used for further analysis.

The components contained in the extract were analyzed by their compounds by colour test (qualitative) with several reagents. Alkaloids contain nitrogen as part of the cyclic system and contain various substituents such as amine groups, amides, phenols, and methoxy so that alkaloids are semipolar [14]. Triterpenoid compounds have cyclic structures in the form of alcohol which causes these compounds to tend to be semipolar. Sapponins are triterpene glycosides which have polar tendencies its glycosidic bonds [15].

Flavonoids have a bond with a sugar group which causes the flavonoids to be polar, so that in the flavonoid test the solvent is replaced into a more polar solvent. Methanol solvent is a solvent used in flavonoid tests which are more polar than chloroform with a polarity level of around 4.1.

The result of phytochemical screening of ethanol extracts were shown in the Table 1.

Table 1. The Result of Experiment

\begin{tabular}{|c|c|c|c|}
\hline No. & Test & Result & Appearence \\
\hline 1. & Alkaloid Identification & +++ & $\begin{array}{l}\text { Yellow precipitate } \\
\text { (Mayer test) } \\
\text { Brown precipitate } \\
\text { (Wagner test) } \\
\text { Orange precipitate } \\
\text { (Dragendorff test) }\end{array}$ \\
\hline 2. & Flavonoid Identificaion & + & Light red \\
\hline 3. & Terpenoid Identification & ++ & Orange \\
\hline 4. & Steroid Identification & - & No clear \\
\hline 5. & Sapponins Identification & + & Foam \\
\hline
\end{tabular}

\subsection{Alkaloid Identification}

The precipitation in Mayer, Wagner and Dragendorff identification ensure the presence of alkaloid compounds in the ethanol extract. The aim of adding of sulphuric acid is because of the properties of alkaloid which is base. Therefore, it should be extracted in the acid solvents [16].

The positive result of Mayer test was confirmed by yellow precipitate. It was expected as a complex of potassium-alkaloid. In the formation of Mayer reagent, the solution of mercury (II) chloride was added by potassium iodide and produced a red precipitate of

42 IEKSAKTA: Berkala IImiah Bidang MIPA

(Science Periods EKSAKTA of MIPA) 
Mercury (II) iodide. The excess of potassium iodide addition introduce to potassium tetraiodomercurate(II) formation [17]. Alkaloids consist of nitrogen atoms which have lone pair electrons. The lone pair electrons are examined to form covalent coordinate bonding with metal ion [18]. In alkaloid identification with Mayer reagent, the nitrogen in alkaloids was predicted to react with metal ion of potassium $\left(\mathrm{K}^{+}\right)$from potassium tetraiodomercurte(II) producing a complex of potassium-alkaloid precipitating. The reaction was proposed as Figure 1.

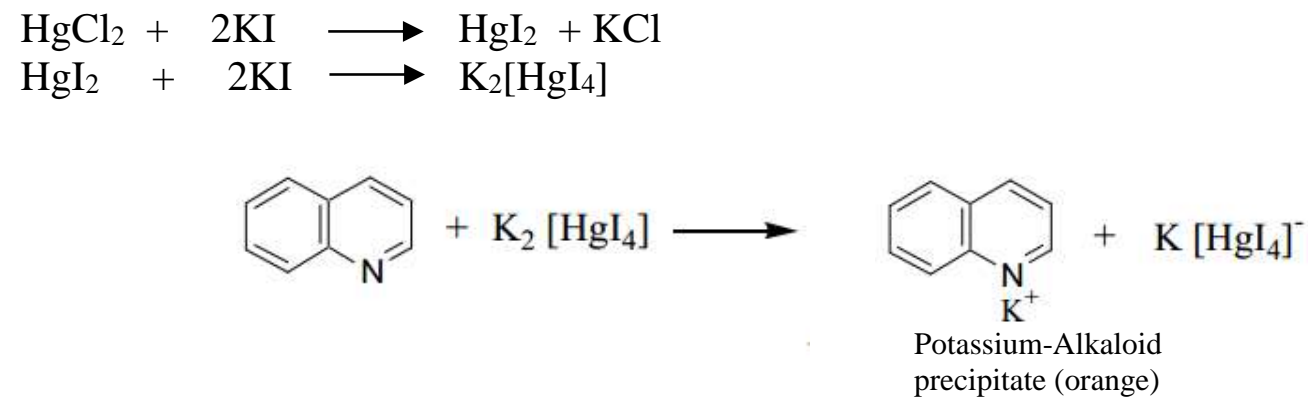

Figure 1. Proposed reaction of Mayer test

The positive results of alkaloid test in Wagner test was confirmed by the presence of brownish to yellowish precipitate. The precipitate was predicted as the presence of potassium-alkaloid. In Wagner reagent preparation, iodine reacts with $\mathrm{I}^{-}$ion from potassium iodide producing $\mathrm{I}^{3-}$ ion (brownish solution). In the Wagner test, the metal ion of $\mathrm{K}^{+}$will bind as covalent coordinate bonding with nitrogen to alkaloid producing a complex precipitate of potassium-alkaloid. The reaction is predicted as Figure 2.

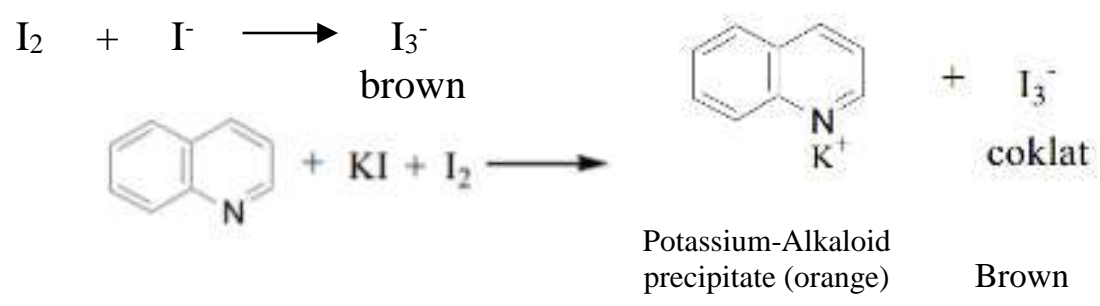

Figure 2. Proposed reaction of Wagner test

The positive result of alkaloid identification in Dragendorff test was as well identified as brownish or yellowish precipitate. The precipitate comes from complex compound of potassium-alkaloid. In Dragendorff reagent preparation, bismuth nitrate was dissolved in hydrochloric acid protecting to hydrolisis reaction because salts of bismuth are easily hydrolised producing $\mathrm{BiO}^{+}$ion. The reaction was proposed as Figure 3 .

$\mathrm{Bi}^{3+}+\mathrm{H}_{2} \mathrm{O} \longrightarrow \mathrm{BiO}^{+}+2 \mathrm{H}^{+}$

The hydrolisis reaction will control the presence of $\mathrm{Bi}^{3+}$ ion in the solution. Therefore, the solution should be added an acid compound and moved the equilibrium to left. Moreover, $\mathrm{Bi}^{3+}$ ion from bismuth nitrate may react to potassium iodide producing dark browninsh precipitate of Bismuth (III) iodide and dissolved in the excess of potassium iodide producing potassium tetraiodobismuthate [17].

41 IEKSAKTA: Berkala IImiah Bidang MIPA (Science Periods EKSAKTA of MIPA) 
In the alkaloid identification of Dragendroff test, nitrogen acted to form covalent coordination bond with $\mathrm{K}^{+}$ion (metal ion). The reaction is proposed as Figure 4 [19].

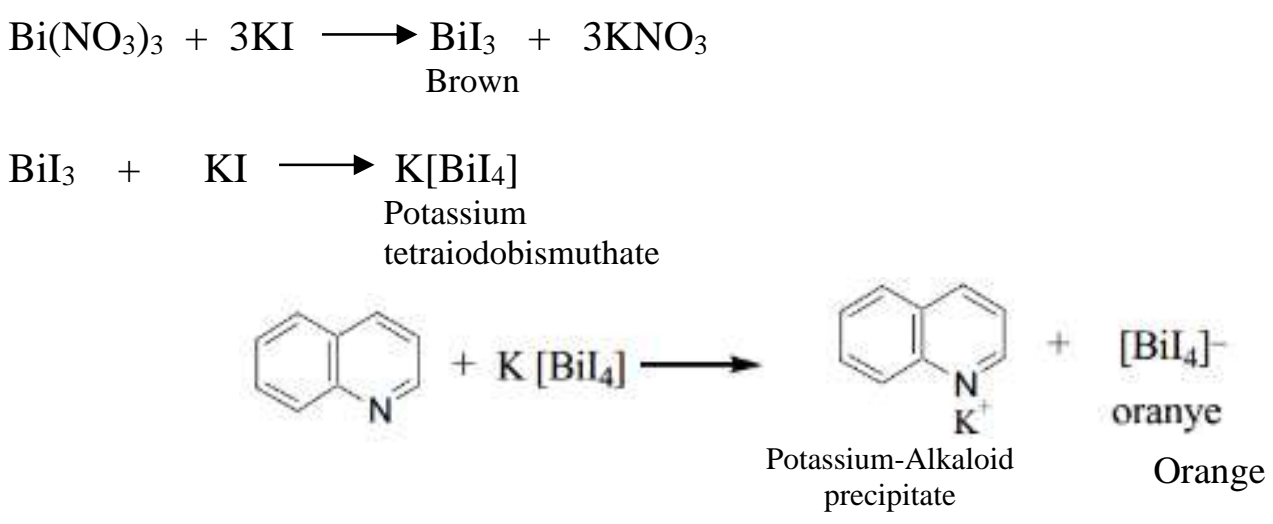

Figure 4. Proposed reaction for Dragendroff test

\subsection{Flavonoid Identification}

Addition of magnesium powder and hydrochloric acid to flavonoid testing will cause the reduction of flavonoid compounds that exist, causing a red reaction that is characteristic of flavonoids. In flavonoid testing, it is positive in this test because there is a colour changing to redish solution.<smiles>O=c1c(O)c(-c2ccc(O)c(O)c2)oc2cc(O)cc(O)c12</smiles><smiles>OC1=C(c2ccc(O)c(O)c2)Oc2cc(O)cc(O)c2C1O</smiles>

Figure 5. Proposed reaction for Flavonoid Identification

Septyaningsih (2010) explained that if extracted samples containing flavonoid compounds, the addition of $\mathrm{Mg}$ and $\mathrm{HCl}$ would form flavium salt which is red or orange.

\subsection{Steroid/Terpenoid Identification}

Steroid/terpenoid screening is based on the ability of compounds to form concentrated $\mathrm{H}_{2} \mathrm{SO}_{4}$ colours in solvents of acetic acid anhydride [15] red orange or purple for terpenoids

42 IEKSAKTA: Berkala IImiah Bidang MIPA

(Science Periods EKSAKTA of MIPA) 
and blue for steroids. The results obtained from testing the ethanol extract of itchy leaves showed a positive result with a marked reddish colour change indicating triterpenoid content.<smiles>CC(=O)OC(C)=O</smiles><smiles>CC1CCC(C(C)C)C(O)C1</smiles><smiles>CC(=O)OC1CC(C)CCC1C(C)C</smiles>

Figure 6. Proposed reaction for Steroid Identification

\subsection{Sapponins Identification}

The foam introducing in sapponin test proving the presence of glycosides that have an abality to produce foam in water hydrolised in glucose and other compounds [20]. The reaction of foam production describes in Figure 7.

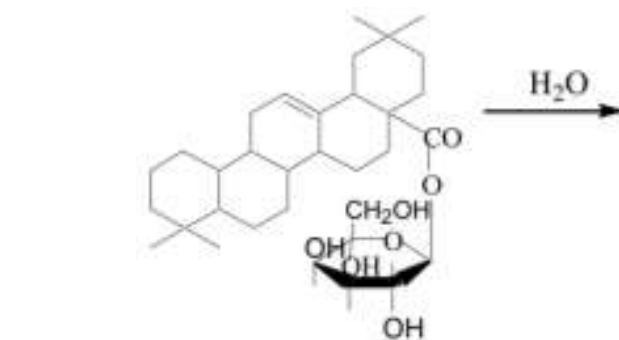

1-Arabinopiriosyl-3 $\beta$-asetyl oleanoleic

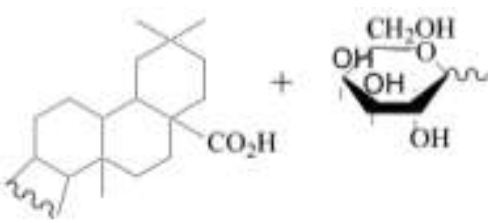

Aglycone

Glucose

Figure 7. Hydrolisis reaction of Sapponins in water

Sapponins contain of glycosyls as polar groups while steroids and triterpenoids as nonpolar groups. The compound containing polar and nonpolar groups are surface active compounds. When they are shaked strongly with water, sapponins would form miscellanea. In the miscellanea, polar groups face to the outside and nonpolar groups face in the inside. This phenomenon is called as foam. In this study, the form formation is not too much. It is predicted because the quantity between steroids and triterpenoids in cocoa leaves are not too much.

The next test is Lieberman-Burchard test which is the test of unsaturated sterol and triterpena [21]. This analysis was based on the ability of triterpenoid and steroid compounds forming colour with concentrated $\mathrm{H}_{2} \mathrm{SO}_{4}$ in anhydride acetic acid. The positive result was given a redish orange for triterpenoid compounds and blue for steroid compounds.

\section{Conclusion}

The cacao leaves (Theobroma cacao L.) is the source of the secondary metabolites ranging from alkaloid, flavonoid, terpenoid, and sapponin compounds. The phytochemical screening of the plant plays an important role for pharmaceutical studies especially discovering new potensial drugs for treatment of various diseases. Further purification, identification and characterisation of the bioactive chemical constituents' compounds would be priority in future studies especially for quantitative analysis.

43 IEKSAKTA: Berkala IImiah Bidang MIPA (Science Periods EKSAKTA of MIPA) 


\section{References}

[1] Kumari N, Grimbs A, D'Souza RN, Verma SK, Corno M, et al. 2018. Origin and varietal based proteomic and peptidomic fingerprinting of Theobroma cacao in nonfermented and fermented cocoa beans. Food research international 111:137-47

[2] Lewis C, Lennon AM, Eudoxie G, Umaharan P. 2018. Genetic variation in bioaccumulation and partitioning of cadmium in Theobroma cacao L. The Science of the total environment 640-641:696-703

[3] Livingstone Iii D, Stack C, Mustiga GM, Rodezno DC, Suarez C, et al. 2018. Corrigendum: A Larger Chocolate Chip-Development of a 15K Theobroma cacao L. SNP Array to Create High-Density Linkage Maps. Frontiers in plant science 9:948

[4] Maciel LF, Felicio A, Miranda LCR, Pires TC, Bispo EDS, Hirooka EY. 2018. Aflatoxins and ochratoxin A in different cocoa clones (Theobroma cacao L.) developed in the southern region of Bahia, Brazil. Food additives \& contaminants. Part A, Chemistry, analysis, control, exposure \& risk assessment 35:134-43

[5] McElroy MS, Navarro AJR, Mustiga G, Stack C, Gezan S, et al. 2018. Prediction of Cacao (Theobroma cacao) Resistance to Moniliophthora spp. Diseases via GenomeWide Association Analysis and Genomic Selection. Frontiers in plant science 9:343

[6] Millaty, Radheta; Anwar, Asrul; Fitriani, Miranti Sari. 2017. "Faktor Teknik Budidaya Yang Mempengaruhi Produktivitas Tanaman Kakao (Theobroma Cacao L.) Di Kecamatan Kumpeh Kabupaten Muaro Jambi”. Skripsi, Fakultas Pertanian Universitas Jambi, Jambi, Indonesia.

[7] Gunawan; Werdhany, Wiendarti Indri; Budisatria, I Gede Suparta. Pengaruh Pemberian Pakan Daun Kakao Terhadap Pertambahan Bobot Badan Kambing (Studi Pada Petani Di Desa Banjarharjo Kulon Progo). 2017. Buletin Peternakan. Vol. 41 (4): 414-419.

[8] Supriyanto; Darmadji, Purnama; Susanti, Iik. Studi Pembuatan Teh Daun Tanaman Kakao (Theobroma Cacao L) Sebagai Minuman Penyegar. Agritech. 2014. Vol. 34 No. 4.

[9] Hernani \& Raharjo, 2006. Tanaman Berkhasiat Sebagai Antioksidan Penebar Swadaya, Jakarta.

[10] Foye, W.O., T.L. Lemke; D.A. Williams, 2008. Foye's Principles of Medicinal Chemistry. 6th Ed Lippincott Williams And Wilkins. Philadelphiap., 44-45.

[11] Gordon, M.C., And J.N. David, 2001. Natural Product Drug Discovery In The Next Millennium. Pharm. Biol. 39 Suppl., 1: 8-17.

[12] Astuti, J.; Rudiyansyah; Gusrizal. Uji Fitokimia Dan Aktivitas Antioksidan Tumbuhan Paku Uban (Nephrolepis biseratta (Sw) Schhnott). Jkk. 2013. 2(2):118122.

[13] Atmoko, T.; Ma'ruf, A. Uji Toksisitas dan Skrining Fitokimia Ekstrak Tumbuhan Sumber Pakan Orangutan Terhadap Larva Artemia Salina L., Penelitian Hutan Dan Konservasi Alam. 2009. Vi (I): 37-45.

[14] Dewi, I. D. A. D. Y.; Astuti, K. W.; Warditiani, N. K.; Skrining Fitokimia Ekstrak Etanol 95\% Kulit Buah Manggis (Garcinia Mangostana L.). Jurnal Farmasi Udayana. 2013.

44 IEKSAKTA: Berkala IImiah Bidang MIPA (Science Periods EKSAKTA of MIPA) 
[15] Sangi, M. S.; Momuat, L. I.; Kumaunang, M. 2013. Uji Toksisitas dan Skrining Fitokimia Tepung Gabah Pelepah Aren (Arange Pinnata). Manado: Universitas Sam Ratulangi.

[16] Harbourne, J., 1996. Metode Fitokimia: Penuntun Cara Modern Menganalisis Tumbuhan. Cetakan Kedua. Penerjemah: Padmawinta, K.; Soediro, I. Bandung: Penerbit ITB.

[17] Altemimi, Ammar; Lakhssassi, Naoufal; Baharlouei, Azam; Watson, Dennis G.; Lightfoot, David A., (Review) Phytochemicals: Extraction, Isolation, and Identification Of Bioactive Compounds From Plant Extracts. Plants. 2017, 6, 42.

[18] Svehla, G. 1990. Buku Teks Analisis Anorganik Kualitatif Makro dan Semimakro. Edisi Kelima. Penerjemah: Setiono, L.; Pudjaatmaka, A. H. Jakarta: Pt Kalman Media Pustaka.

[19] Miroslav, V. 1971. Detection And Identification Of Organic Compound. New York: Planum Publishing Corporation and Sntc Publishers Of Technical Literatur.

[20] Rusdi. 1990. Tetumbuhan Sebagai Sumber Bahan Obat. Padang: Pusat Penelitian Universitas Andalas.

[21] Santos, A.F., B.Q. Guevera, A.M. Mascardo, and C.Q. Estrada. 1978. Phytochemical, Microbiological And Pharmacological, Screening Of Medical Plants. Manila: Research Center University Of Santo Thomas. 